\title{
The Effect of Competence, Leadership and Work Environment to the Employee Performance
}

\author{
Ngatimun $^{1 *} \quad$ Muhammad Syarif Hidayatullah Elmas ${ }^{2} \quad$ Seger Priantono ${ }^{3}$ \\ 1.Panca Marga University of Probolinggo. Address: Engas RT 10 RW 4 Alas Pandan Village, Pakuniran District, \\ Probolinggo, East Java Province, Indonesia \\ 2.Panca Marga University of Probolinggo. Address: Krajan RT 1 RW 1 Sambirampak Kidul Village, Kotaanyar \\ District, Probolinggo, East Java Province, Indonesia \\ 3.Panca Marga University of Probolinggo. Address: Gubernur Suryo Street RT 4 RW 9 Kanigaran District, \\ Probolinggo, East Java Province, Indonesia
}

\begin{abstract}
Rising of social welfare problems like, bad boy, neglected elderly, homeless, poor families etc in Probolinggo reflected the fact that problems are more the strengthened, it is as the consequence of goverment role that more powerful as the center of social economic development.This study used a quantitative approach which is used to analyze certain sample and population that is representative. Research design uses explanatory method which explained the effects of each variables. Population of this study are all of the employees in Social Department Probolinggo that are 52 person. This study also uses inteviews and documentaries for completing. Data analysis uses multiple regression analysis and determination test. It can be generalized that competence, leadership, and physical environment significanty positive effect on the employee performance in Social Depatment Probolinggo. The result shows that competence is more influent.
\end{abstract}

Keywords: Competence, workplace, leadership, performance.

DOI: $10.7176 / \mathrm{EJBM} / 11-32-10$

Publication date: November $30^{\text {th }} 2019$

\section{Introduction}

Rising of social welfare problems like, bad boy, neglected elderly, homeless, poor families etc in Probolinggo reflected the fact that problems are more the strengthened, it is as the consequence of goverment role that more powerful as the center of social economic development. Probolinggo has vision as a service c environmental advanced city, prosperous and fair. Realizing that vision need all parties to work hard for increasing performance, especially

the insurer government apparatus state civil. Social Department as an executer element local governments in the social field, led by head of department responsible to mayor. Social Department in charge as the social problems not yet optimal social handling matters as mentioned above, proves that have not been optimal performance.Less than optimal the employee performance of Social Department in Probolinggoare influenced by various factors such as: leadership, workplace, culture organization, system/procedure compensation, motivation, competence, communication, and others (edison, at.al; 2016).

Less than optimal of employee performance at the Social Department Probolinggo, happen may be due to a lack of competence possessed and leadership and workplace factors. For sharping these problems, this study focused on the influence of performance and leadership of Social Departmen Probolinggo.Research focused of this study are; 1) influence of competence performance; 2) influence of leadership performance; 3) influence of environmental work performance; 4) the biggest influence of Social Department Probolinggo. The objectives of this study is to know the influence of leadership competence and workplace performance for the employees's activities in Social Department Probolinggo.

This study is expected to give description about competence, leadership, and workplace and also the influence of performance. In oher words, the result of this study can be contributed for making decision of officials in order to improve the employee performances in Social Department of Probolinggo.

\section{Method}

\subsection{Search Model}

The competence of official employees can affect the quality of performance. Good competence (knowledge, skill, and behaviour) that owned by employee will result good performance also (Amir, 2015). According to Mitchel, good performance will be affected by competencephase and good motivation (Sinambela, 2016). Both of opinion are strengthened by result of Rande's (2016), Mugiarto et. al (2016), Dharmanegara et. al research, Prasetio (2014), Fadud et. al (2019) concluded that competence significantly posiive affects to employees' performance.

According to Wibowo (2016) style of leadership has important role in organization in order to affect the employees' performance. Leadership can create employees' performance. Empirically, results of Nalasatria et. al (2013), Sasingkelo (2016), Bahrum (2015), Djuremi et. al (2016), Fadude et. al (2019), Jannah (2019) conclude 
that leadership significantly affect on performance.

Sadarmayanti (2011) revealed that physical environment in workplace can affect on employee's peformance. It is supported Tjiabarata's research (2017), Zulkifli (2016), Jansen (2019), Dharmanegara et. al (2016), Djuremi et. al (2016), Yudistiro (2015), Jannah (2019) concluded that environment workplace is significantly affect on performance.

\subsection{The Framework}
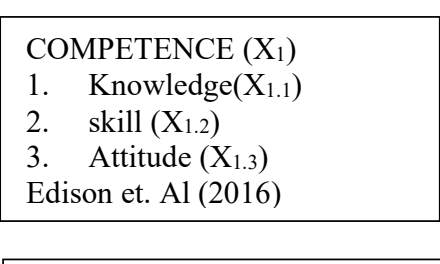

LEADERSHIP $\left(\mathrm{X}_{2}\right)$
1) Have a strategy

1) Have a strategy $\left(X_{2} .1\right)$

2) Care $\left(X_{2} .2\right)$

3) Stimulating member $\left(X_{2} .3\right)$

4) Keep compactness $\left(X_{2} .4\right)$

5) Celebrate diversity and confidence $\left(\mathrm{X}_{2} .5\right)$

Schermerhorn on Edison (2016)

WORK ENVIRONMENT $\left(\mathrm{X}_{3}\right)$

1) light $\left(X_{3.1}\right)$

2) temperature $\left(X_{3.2}\right)$

3) moisture $\left(X_{3.3}\right)$

4) air circulation $\left(X_{3.4}\right)$

5) noise $\left(X_{3.5}\right)$

6) mechanical vibrations $\left(X_{3.6}\right)$

7) odoriferous $\left(X_{3.7}\right)$

8) full color $\left(X_{3.8}\right)$

9) decoration $\left(X_{3.9}\right)$

10) music $\left(X_{3.10}\right)$

11) safety $\left(X_{3.11}\right)$

Sedarmayanti (2011)

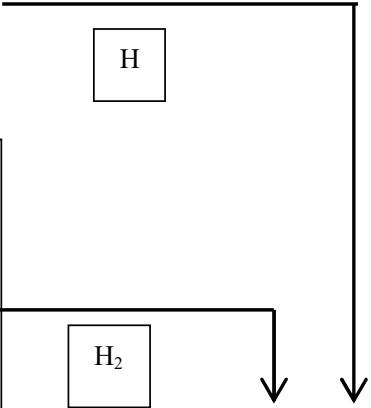

EMPLOYEE PERFORMANCE(Y)

1) quality $\left(Y_{1}\right)$

2) quantity $\left(\mathrm{Y}_{2}\right)$

3) time $\left(Y_{3}\right)$

4) teamwork $\left(\mathrm{Y}_{4}\right)$

Mathis \& Jackson (2006).

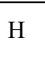

a) Rande (2016), Murgianto et. al (2016), Dharmanegara et. al (2016), Prasetio (2014), Fadude et. al (2019)

b) Sasingkelo (2016), Bahrum (2015), Djuremi et. al(2016), Fadude et. al(2019), Jannah (2019)

c) Tjiabrata (2017), Zulkifli (2016), Jansen (2019), Dharmanegara et. al(2016), Djuremi et. al(2016), Yudistiro (2015), Jannah (2019)

\subsection{Hypothesis}

Based on existing theories, there are several hypothesis proposed in this study:

H1: There is competence's influence on the employee's performance in Social Department of Probolinggo.

H2: There is leadeship's influence on the employee's performance in Social Department of Probolinggo.

H3: There is environment's influence on employee's performance in Social Department of Probolinggo.

$\mathrm{H} 4$ : Competence is the most influence factors on employee's performance.

\section{Collecting Data and Analysis}

This study used quantitative approach which used to analyze population or representative sample (Sugiyono, 2014). Research design of this study used explantory methods which explained the influenced of each variables. Population of this study is all of official employee, that are 52 employee did not include the head office because of analyzing leadership. The population least than 100 employee, that is all of population being respondence in order not to be difficult to learn of population (Sugiyono, 2014).

Collecting data used questionnair method by distributing the questionnaire that related to variables' indicators. The data will be analyzed by using statistic inferencial in order to be concluded the hypothesis. Interviewing and documentation are used for completing this study. Analyzing data method is multiple 
regression analysis and determination test.

Multiple linear regression analysis measured the competence influenced $\left(\mathrm{X}_{1}\right)$, leadership $\left(\mathrm{X}_{2}\right)$, work environment $\left(\mathrm{X}_{3}\right)$ as independent variables on performance as dependent variable $(\mathrm{Y})$. The formula is below (Sugiyono, 2014):

$$
\mathbf{Y}=\mathbf{a}+\mathbf{b}_{1} \mathbf{X}_{1}+\mathbf{b}_{2} \mathbf{X}_{2}+\mathbf{b}_{3} \mathbf{X}_{3}+\mathbf{b}_{4} \mathbf{X}_{4}
$$

According to Ghozali (2011: 97), "coefisien determination $\left(\mathrm{R}^{2}\right)$ is measure the ability in measuring the variant of dependent variables". The value of coefisien determination approximately zero and one. The least $\left(\mathrm{R}^{2}\right)$ value means the ability of independent variables is limited for explaining dependent variabel's variance. The value close to one means that independent variables give almost all information required to predict dependent variable's variance.

\section{Results}

\subsection{Variable Competence}

The frequency of the answer for variable competencies as follows:

Table 1. Competence Variable

\begin{tabular}{|c|c|c|c|c|c|c|c|c|c|c|}
\hline \multirow{2}{*}{ Alt } & \multicolumn{8}{|c|}{ Item } & \multirow{2}{*}{$\sum$} & \multirow{2}{*}{$\%$} \\
\hline & 1 & 2 & 3 & 4 & 5 & 6 & 7 & 8 & & \\
\hline Strongly Agree & 4 & 6 & 4 & 7 & 8 & 4 & 2 & 5 & 40 & 10 \\
\hline Agree & 33 & 32 & 34 & 29 & 31 & 36 & 41 & 37 & 273 & 66 \\
\hline Could not Agree & 14 & 11 & 11 & 13 & 11 & 9 & 9 & 7 & 85 & 20 \\
\hline Disagree & 1 & 3 & 3 & 3 & 2 & 3 & 0 & 3 & 18 & 4 \\
\hline Strongly Disagree & 0 & 0 & 0 & 0 & 0 & 0 & 0 & 0 & 0 & 0 \\
\hline$\Sigma$ & 52 & 52 & 52 & 52 & 52 & 52 & 52 & 52 & 416 & 100 \\
\hline Average & 3,76 & 3,78 & 3,75 & 3,77 & 3,87 & 3,79 & 3,87 & 3,85 & & \\
\hline
\end{tabular}

Source : The primary data processed 2019

Tabel 1 was known10\% respondences revealed that do agree, $66 \%$ agree, $20 \%$ less agree, and $4 \%$ do not agree. This result shows thatmost of civil servants have high comptence on their work based on their knowledge, competence, and behaviour of civil servant who are being faced in Social Department Probolinggo. It is the most contributed on their competence.

\subsection{Leadership Variables}

Frequency for variables leadership answer as follows:

Table 2. Variables Leadership

\begin{tabular}{|c|c|c|c|c|c|c|c|c|c|c|c|c|c|c|c|}
\hline \multirow{2}{*}{ Alt } & \multicolumn{13}{|c|}{ Item } & \multirow{2}{*}{$\Sigma$} & \multirow{2}{*}{$\%$} \\
\hline & 1 & 2 & 3 & 4 & 5 & 6 & 7 & 8 & 9 & 10 & 11 & 12 & 13 & & \\
\hline Strongly Agree & 17 & 14 & $\begin{array}{l}1 \\
2\end{array}$ & 9 & 8 & 12 & 11 & 10 & 10 & 16 & 10 & 13 & 14 & $\begin{array}{c}15 \\
6\end{array}$ & 23 \\
\hline Agree & 31 & 37 & $\begin{array}{l}2 \\
8\end{array}$ & 30 & 31 & 32 & 27 & 30 & 34 & 31 & 30 & 31 & 36 & $\begin{array}{c}40 \\
8\end{array}$ & 60 \\
\hline Could not Agree & 4 & 1 & $\begin{array}{l}1 \\
2 \\
\end{array}$ & 12 & 13 & 8 & 13 & 11 & 8 & 4 & 12 & 6 & 2 & $\begin{array}{c}10 \\
6 \\
\end{array}$ & 16 \\
\hline Disagree & 0 & 0 & 0 & 1 & 0 & 0 & 1 & 1 & 0 & 1 & 0 & 2 & 0 & 6 & 1 \\
\hline $\begin{array}{l}\text { Strongly } \\
\text { Disagree }\end{array}$ & 0 & 0 & 0 & 0 & 0 & 0 & 0 & 0 & 0 & 0 & 0 & 0 & 0 & 0 & 0 \\
\hline$\sum$ & 52 & 52 & $\begin{array}{l}5 \\
2\end{array}$ & 52 & 52 & 52 & 52 & 52 & 52 & 52 & 52 & 52 & 52 & $\begin{array}{c}67 \\
6\end{array}$ & $\begin{array}{c}10 \\
0\end{array}$ \\
\hline Average & $\begin{array}{c}4.2 \\
5 \\
\end{array}$ & $\begin{array}{c}4.2 \\
5 \\
\end{array}$ & 4 & $\begin{array}{l}3 . \\
9\end{array}$ & $\begin{array}{l}3 . \\
9\end{array}$ & $\begin{array}{c}4.0 \\
8 \\
\end{array}$ & $\begin{array}{c}3.9 \\
2 \\
\end{array}$ & $\begin{array}{c}3.9 \\
4 \\
\end{array}$ & $\begin{array}{c}4.0 \\
3 \\
\end{array}$ & $\begin{array}{c}4.1 \\
9 \\
\end{array}$ & $\begin{array}{c}3.9 \\
6 \\
\end{array}$ & $\begin{array}{c}4.0 \\
6 \\
\end{array}$ & $\begin{array}{c}4.2 \\
3 \\
\end{array}$ & & \\
\hline
\end{tabular}

Source : The primary data processed 2019

Table 2 was known that 23\% revealed do agree, $60 \%$ wass agree, $16 \%$ was less agreement and $1 \%$ respondence revelaed do not agree. This result shows that leadership has been implemented well eventhough there are some respondences revea that not so agree on their leader who do not care of their worker. The most apprecited leadership by civil sevant is having organization strategy and can be communicated well, especially having clear and realistic organization stratgic for the improvement. 


\subsection{Variable Work Environment}

The frequency of the answer for variable work environment as follows:

Table 3. Variable Work Environment

\begin{tabular}{|c|c|c|c|c|c|c|c|c|c|c|c|c|c|}
\hline \multirow{2}{*}{ Alt } & \multicolumn{11}{|c|}{ Item } & \multirow{2}{*}{$\Sigma$} & \multirow{2}{*}{$\%$} \\
\hline & 1 & 2 & 3 & 4 & 5 & 6 & 7 & 8 & 9 & 10 & 11 & & \\
\hline Strongly Agree & 21 & 11 & 12 & 7 & 5 & 6 & 15 & 13 & 9 & 7 & 8 & 114 & 20 \\
\hline Agree & 26 & 33 & 31 & 26 & 32 & 31 & 28 & 30 & 27 & 35 & 27 & 326 & 57 \\
\hline Could not Agree & 4 & 3 & 6 & 15 & 13 & 12 & 6 & 7 & 13 & 9 & 15 & 103 & 18 \\
\hline Disagree & 1 & 5 & 3 & 4 & 2 & 2 & 3 & 2 & 3 & 1 & 2 & 28 & 5 \\
\hline Strongly Disagree & 0 & 0 & 0 & 0 & 0 & 1 & 0 & 0 & 0 & 0 & 0 & 1 & 0 \\
\hline$\sum$ & 52 & 52 & 52 & 52 & 52 & 52 & 52 & 52 & 52 & 52 & 52 & 572 & 100 \\
\hline Average & 4.29 & 3.96 & 4 & 3.69 & 3.76 & 3.75 & 4.05 & 4.03 & 3.81 & 3.92 & 3.79 & & \\
\hline
\end{tabular}

Source : The primary data processed 2019

Table 3 was known that 20\% revealed that do agree, 57\% was agree, $18 \%$ was less agree, $5 \%$ disagree. This result indicates that work environment are adequated workplace, lighting, moist air, the fresh air, and guarantee of vehicle security that are used by employees. The physical environment is the most appreciated by civil servant of Social Department Probolinggo, that is lighting in Social Department based on thier requirement.

\subsection{Employee's Performance Variable}

The frequency of the answer to variable employee performance as follows :

Table 4. Employee's Performance Variable

\begin{tabular}{|c|c|c|c|c|c|c|c|c|c|c|c|}
\hline \multirow{2}{*}{ Alt } & \multicolumn{9}{|c|}{ Item } & \multirow{2}{*}{$\Sigma$} & \multirow{2}{*}{$\%$} \\
\hline & 1 & 2 & 3 & 4 & 5 & 6 & 7 & 8 & 9 & & \\
\hline Strongly Agree & 18 & 13 & 20 & 19 & 14 & 16 & 22 & 14 & 20 & 156 & 33 \\
\hline Agree & 33 & 37 & 28 & 26 & 31 & 29 & 26 & 33 & 29 & 272 & 58 \\
\hline Could not Agree & $\mathbf{0}$ & 1 & 4 & 7 & 4 & 6 & 4 & 3 & 2 & 31 & 7 \\
\hline Disagree & 1 & 1 & $\mathbf{0}$ & $\mathbf{0}$ & 3 & 1 & $\mathbf{0}$ & 2 & 1 & 9 & 2 \\
\hline Strongly Disagree & $\mathbf{0}$ & $\mathbf{0}$ & $\mathbf{0}$ & $\mathbf{0}$ & $\mathbf{0}$ & $\mathbf{0}$ & $\mathbf{0}$ & $\mathbf{0}$ & $\mathbf{0}$ & $\mathbf{0}$ & $\mathbf{0}$ \\
\hline$\sum$ & 52 & 52 & 52 & 52 & 52 & 52 & 52 & 52 & 52 & 468 & 100 \\
\hline Average & 4.31 & 4.19 & 4.31 & 4.23 & 4.08 & 4.15 & 4.35 & 4.13 & 4.31 & & \\
\hline
\end{tabular}

Source : The primary data processed 2019

Table 4 can be seen that 33\% revelaed do agree, 58\% was agree, $7 \%$ was less agreement, $2 \%$ was disagree. This result indicates that the employee's performance are well, eventhough there were several lack of employee's performance and any workload. This statement maximize the work time and no waste time useless in this performance.

\subsection{The Validity Test}

The test result of validity showed that the value of all intruments of each vaiable, they are competence, leadership, work environment, and performance are above of the value (bigger) from 0,273 ( $\mathrm{r}_{\text {table }}$ ) are categorized as valid.

\subsection{The Realibility Test}

Reliability test results obtained the as table 5 follows:

Table 5. Reability Test

\begin{tabular}{|c|c|c|c|}
\hline Variable & Cronbach's Alpha & Critical Value & Desc \\
\hline $\mathrm{X}_{1}$ & 0.468 & $0,401-0,600$ & It is reliable enough \\
\hline $\mathrm{X}_{2}$ & 0.506 & $0,401-0,600$ & It is reliable enough \\
\hline $\mathrm{X}_{3}$ & 0.431 & $0,401-0,600$ & It is reliable enough \\
\hline $\mathrm{Y}$ & 0.534 & $0,401-0,600$ & It is reliable enough \\
\hline
\end{tabular}

Source : The primary data processed 2019

Reliability of the trial in table 5 showed that the cronbach' s alpha all the variables is enough reliabeland can be used to further analysis.

\subsection{The Normality Test}

The results of the normality show results as follows: 
Table 6. Normality Test

One-Sample Kolmogorov-Smirnov Test

\begin{tabular}{|ll|r|}
\hline & & \multicolumn{2}{|c|}{$\begin{array}{l}\text { Unstandardized } \\
\text { Residual }\end{array}$} \\
\hline $\mathrm{N}$ & & 52 \\
Normal & Mean & .0000000 \\
Parameters ${ }^{\mathrm{a}} \quad$ Std. Deviation & 2.80756018 \\
Most Extreme & Absolute & .075 \\
Differences $\quad$ Positive & .066 \\
& $\quad$ Negative & -.075 \\
Kolmogorov-Smirnov Z & .541 \\
Asymp. Sig. (2-tailed) & .932 \\
\hline
\end{tabular}

a. Test distribution is Normal.

Source : The primary data processed 2019

The table shows that the value of p-value (significance) Asymp. Sig (2-tailed) worth 0,93 $>0,05$ and concluded that the normal distribution to the residual .

\subsection{The Multikolinierity Test}

The table below the multikolinearity as:

Table 7. Multikolinierity test

\begin{tabular}{|l|r|r|}
\hline \multirow{2}{*}{ Model } & \multicolumn{2}{|c|}{ Collinearity Statistics } \\
\cline { 2 - 3 } & Tolerance & \multicolumn{1}{|c|}{ VIF } \\
\hline $\mathrm{X}_{1}$ &, 990 & 1,010 \\
$\mathrm{X}_{2}$ &, 682 & 1,466 \\
$\mathrm{X}_{3}$ &, 677 & 1,476 \\
\hline
\end{tabular}

Source : The primary data processed 2019

From the multikolinerity test in table 7 it can be seen that variable competence, leadership, and workplace all with the tolerance and value vif smaller than 10, means that all the variables free not a problem multikolinearity .

\subsection{The Autocorrelation Test}

The data as the autocorrelation table below:

Table 8. Auto Correlation Test

\section{Model Summary ${ }^{b}$}

\begin{tabular}{|l|c|r|r|r|r|}
\hline Model & $\mathrm{R}$ & $\mathrm{R}$ Square & Adjusted R Square & Std. Error of the Estimate & Durbin-Watson \\
\hline 1 & $.743^{\mathrm{a}}$ & .552 & .524 & 2.894 & 2.246 \\
\hline
\end{tabular}

a. Predictors: (Constant), X3, X1, X2

b. Dependent Variable: Y

Source : The primary data processed 2019

Test results on autocorrelation are known that the values of 2,246, Durbin Watson because the DW test ranges from 1,677 until 2,323, it can conclude that there is no problem auto correlation. 
4.10 The Heterokedastisity Test

Test results heteroskedastisity in table follows :

Table 9. Heterokedastisity Test

Correlations

\begin{tabular}{|c|c|c|c|c|c|c|}
\hline & & & Absres & $x_{1}$ & $x_{2}$ & $\times 3$ \\
\hline \multirow[t]{12}{*}{ Spearman's rho } & \multirow[t]{3}{*}{ AbsRes } & Correlation Coefficient & 1.000 & .191 & .042 & .150 \\
\hline & & Sig. (2-tailed) & & .174 & .767 & .288 \\
\hline & & N & 52 & 52 & 52 & 52 \\
\hline & \multirow[t]{3}{*}{$x 1$} & Correlation Coefficient & .191 & 1.000 & -.026 & .024 \\
\hline & & Sig. (2-tailed) & .174 & & .856 & .868 \\
\hline & & $\mathrm{N}$ & 52 & 52 & 52 & 52 \\
\hline & \multirow[t]{3}{*}{$x 2$} & Correlation Coeficient & .042 & -.026 & 1.000 & $.513^{\prime \prime}$ \\
\hline & & Sig. (2-tailed) & .767 & .856 & & .000 \\
\hline & & $\mathrm{N}$ & 52 & 52 & 52 & 52 \\
\hline & \multirow[t]{3}{*}{$x$} & Correlation Coefficient & .150 & .024 & $.513^{\prime \prime}$ & 1.000 \\
\hline & & Sig. (2-tailed) & .288 & .868 & .000 & \\
\hline & & $\mathbf{N}$ & 52 & 52 & 52 & 52 \\
\hline
\end{tabular}

*. Correlation is significant at the 0.01 level (2-tailed).

Source : The primary data processed 2019

The test result on coefficient correlation of Spearman's rho is more than 0,05 significant for all variables. It can be concluded that there is no heteroskeditasity's matter.

\subsection{Multiple Regression Analysis}

The results obtained a model of multiple regression equation as follows

$$
\mathrm{Y}=19,336+0,779 \times 1-0.289 \times 2+0,225 \times 3
$$

the equation regression it can be described as follows:

a) The value of coefficient regression variable 0,779 are positive. Variable competence tends to reflect in line with the performance of employees if competence the higher then it will affect the increasing of performance. Instead the decreasing competence will impact on the decline in employee's performance.

b) The value of coefficient regression leadership variable is negative, that is - 0,289 . This shows that the variable tends to reflect leadership in line with employee's performance. The low implementation of the leadership will impact the low of employee's performance as well as on the contrary the higher leadership will impact employee's performance.

c) The value of the coefficient regression environment variable was positive in value best work inside the box is as much as 0,225 . The variables reach as high as these kinds of environments have had a limited impact rate which was tending to are in line with the employee's performance. It can get better work environment, it would impact with the increase the performance, contrary of that bad the environment of labor hence sent down the employee's performance.

\subsection{Analysis of determination}

The results of determination as follows :

Table 10. Determination test

Model Summary

\begin{tabular}{|l|c|r|r|r|}
\hline Model & $\mathrm{R}$ & R Square & Adjusted R Square & Std. Error of the Estimate \\
\hline 1 & $.743^{\mathrm{a}}$ & .552 & .524 & 2.894 \\
\hline
\end{tabular}

a. Predictors: (Constant), X3, X1, X2

Source : The primary data processed 2019

Table 10 determined value is 0,524 . It shows that the employee's performance 52,4 percent was described by competence leadership and workplace whichis competence leadership and environmental variations variables in explaining the employee's performance is quite variable.

\section{Discussion}

\section{The First Hypothesis Testing (H1)}

H1 hypothesis reveals there is the influence of performance's competence for servant in Social Department of Probolinggo. It prove that $t$ count $=6.803$ are bigger than $t$ table $=2.311$ or sig $\mathrm{X}_{1}$ value $=0.000$ a smaller than $a$ 
$=0.05$. It can be proved that hypothesis is accepted and competence's variable test on employee's performance is significantly positive. It can conclude that competence significantly influence on employee's performance.

The Second Hypotheses Testing (H2)

$\mathrm{H} 2$ hypothesis shows that there is influence of leadership on employee's performance in Social Department Probolinggo. It proves that the value of $t$ count $=-3,103$ is smaller than $t$ table $=-2.311$ or sig $\mathrm{X}_{2}$ value $=0.003$ smaller than $a=0.05$. It proves that the second hypothesis is accepted and leadership's variable test is significantly negative. It can conclude that leadership significantly influence on employee's performance.

\section{The Third Hypotheses Testing (H3)}

H3 hypothesis reveals that there in influence of work environment on employee's performance in Social Department Probolinggo. It proves that $t$ count $=2.621$ is bigger than $t$ table $=2.311$ or sig $\mathrm{X}_{1}$ value $=0.012$ is smaller than $a=0.05$. It proves that work environment test significantly positive. It can conclude that work environment can influence on employee's performance.

\section{The Fourth Hypotheses Testing (H4)}

H4 hypothesis stated that competence is the most influential on employee's performance. It is proved that $t$ count $=6.803$ is bigger and 0,797 of coefficient determination value is bigger than others independent variable. It means that the fourth hypothesis is accepted. In other word, the competence is the most influential factors on employee's performance.

\section{Conclusion}

1. The competence influence determined employee's performance. Every work fields need competence, whether knowledge, skill, and attitude. The competence will affect employee's competence, Mitchel stated. The previous study by Rande (2016), Murgianto et,. al (2016), Dharmanegara et., al (2016), Prasetio (2014), Fadude et. al (2019) are supported this result which is competence significantly positive effect on employee's performance. The most influential competence is skill, especially able to look for solution of the problem in Social Department Probolinggo.

2. The leadership has influence on employee's performance in an organization. The competence of taking affect other will determine willingness to develop their institution. Wobowo (2016) stated that Leadership's influence will effect on employee's performance. This result is supported by previous study of Nalastaria et. al (2013), Sasingkelo (2016), Bahrum (2015), Djuremi et. al (2016), Fadude et. al (2019), Jannah (2019) which are leadership can positive influence on employee's performance. A better leadership will be better on employee's performance. The most appreciated influence of leadership is having strategic which can communicate well and can accept the servant.

3. The work environment will affect on employee's performance, such as temperature, lighting, color etc. The bad temperature and color will affect someone in working. This is supported Edison et. al (2016) and Sadarmayanti (2011). This study supports Tjiabarata (2017), Zulkifli (2016), Jansen (2019), Dharmanegara et. al (2016), Djuremi et. al (2016), Yudistiro (2015) and Jannah (2019). The most appreciated of physical environment in Social Department Probolinggo is lighting, especially lighting in Social Departmen office Proboling because it depends on requirement.

4. In general, it can be concluded that competence, leadership, and physical work environment significantly positive influence on employee's performance in Social Department Probolinggo. The most influential factor is competence.

\section{References}

Amir, Mohammmad Faisal.2015.Memahami Evaluasi Kinerja Karyawan Konsep dan Penilaian Kinerja Karyawan. Jakarta: Mitra Wacana Media.

Bahrum, Syazhashah Putra., Sinaga, Inggrid Wahyuni., 2015, Pengaruh Kepemimpinan Dan Motivasi Kerja Terhadap Kinerja Pegawai (Studi Pada Pegawai Lembaga Dewan Kawasan Perdagangan Bebas Pelabuhan Bebas Batam Bintan Karimun), Jurnal Akuntansi, Ekonomi Dan Manajemen Bisnis ,Vol. 3, No. 2, 2015, 135-141

Dharmanegara , Ida Bagus Agung. , Sitiari, Ni Wayan., Wirayudha ,I Dewa Gde Ngurah ., 2016, Job Competency And Work Environment: The Effect On Job Satisfaction And Job Performance Among Smes Worker,IOSR Journal of Business and Management (IOSR-JBM) Volume 18, Issue 1.Ver. II p. 19-26, www.iosrjournals.org

Djuremi., Hasiolan, Leonardo Budi., Minarsih, Maria Magdalena, 2016, Pengaruh Lingkungan Kerja, Budaya Organisasi dan Kepemimpinan Terhadap Kinerja Pegawai Pada Dinas Pasar Kota Semarang, Journal of Manajement, Vol. 2 No. 2

Edison, Emron. Dkk. 2016.Manajemen Sumber Daya Manusia. Bandung: ALFABETA.

Fadude, Fikri Djafar., Tawas, Hendra N., Poluan, Jane Grace.,2019, Pengaruh Kepemimpinan, Budaya Organisasi, Dan Kompetensi Terhadap Kinerja Karyawan Pt. Bank Syariah Mandiri Cabang Bitung, Jurnal 
EMBA Vol.7 No.1, Hal. $31-40$

Ghozali, Imam. 2011. Aplikasi Analisis Multivariative Dengan Program IBM SPSS 19. Semarang: Badan Penerbit Universitas Diponegoro

Jannah, Miftahul Khoiriyatul ., 2019, Pengaruh Gaya Kepemimpinan Supervisor Dan LingkunganKerja Terhadap Kinerja Karyawan (Studi Kasus Pada Karyawan Bagian Produksi Cv. Kairos Sukses Sejati,Yogyakarta), Jurnal Ilmu Manajemen, Volume 16, Nomor 1.

Jansen ,Daniel., Kojo , Christoffel. , Dotulong Lucky O.H ., 2019, Pengaruh Perubahan Organisasi, Budaya Organisasi, Dan Lingkungan Kerja Terhadap Kinerja Karyawan Pada Pt. Telkom Area Manado, Jurnal Emba, Vol.7 No.3 , Hal. 2989 - 2998

Mathis, L.R. and Jackson, 2012, Human Resource Management. Ohio: South-Western College Publishing.

Murgianto., Sulasmi, Siti ., Suhermin, 2016, The Effects Of Commitment, Competence, Work Satisfaction On Motivation, And Performance Of Employees At Integrated Service Office Of East Java, International Journal Of Advanced Research Volume 3, Issue -378-396, Journal Homepage: Http://Www.Journalijar.Com

Prasetio, Bambang., Surya, R.Adri Satriawan., Azhari., 2014, Pengaruh Motivasi Kerja, Budaya Organisasi Dan Kompetensi Kerja Terhadap Kinerja Pegawai Bagian Keuangan SKPD Pemerintahan Provinsi Riau, JOM FEKOM Vol. 1 No.2

Rande, Dina., 2016, Pengaruh Kompetensi Terhadap Kinerja Pegawai Pada Dinas Perhubungan, Komunikasi Dan Informatika Kabupaten Mamuju Utara , E Jurnal Katalogis, Volume 4 Nomor 2, Februari 2016 Hlm 101-109

Sasingkelo, Reni ., Kojo, Christoffel ., Rumokoy, Farlane S., 2016, Pengaruh Gaya Kepemimpinan Dan Budaya Organisasi Terhadap Kinerja Keryawan Pada Pt.Horiguchi Sinar Insani , Jurnal Emba Vol.4 No.4, Hal. $2107-2114$

Sedarmayanti.2007. Manajemen Sumber Daya Manusia Reformasi Birokrasi dan Manajemen Pegawai Negeri Sipil. Bandung: PT Refika Aditama.

Sinambela, Lijan Poltak.,2016, Manajemen Sumber Daya Manusia, Bumi Aksara, Jakarta.

Sugiyono. 2014. Metode Penelitian Kuantitatif Kualitatif dan R\&D. Bandung: Alfabeta

Tjiabrata , Fernando Reinhard., Lumanaw ,Bode., Dotulong, Lucky O.H. , 2017, Pengaruh Beban Kerja Dan Lingkungan Kerja Terhadap Kinerja Karyawan Pt. Sabar Ganda Manado, Jurnal Emba Vol.5 No.2 Juni 2017, Hal. 1570-1580

Wibowo. 2016. Manajemen Kinerja Edisi Kelima. Jakarta: Rajawali Pers.

Yudistiro, Indra Agung., 2015, Pengaruh Kecerdasan Emosional, Lingkungan Kerja Dan Disiplin Terhadap Kinerja Guru Dengan Komitmen Organisasi Sebagai Moderasi, Jurnal Manajemen Sumberdaya Manusia Vol. 9 No. 1 Juni 2015: $38-50$

Zulkifli., 2016, Pengaruh Beban Kerja, Lingkungan Kerja Dan Kompensasi Terhadap Kinerja Dosen Universitas Jabal Ghafur, Journal Of Economic Management \& Business, Vol. 17, No. 1. 